\title{
PRIROČNIK ZA SPOZNAVANJE PRSTI NA TERENU
}

Ana VOVK KORŽE in Franc LOVRENČAK, Maribor, Ljubljana, 2004, Oddelek za geografijo Filozofske fakultete Univerze v Ljubljani, 49 strani (ISBN 96I-237-105-9)

Leta 2001 je izšel priročnik za laboratorijske analize prsti v geografiji, ki je bil izjemno dobro sprejet. Priročnik je namreč že pošel in pripravlja se ponatis. Vendar pa je temelj geografskega proučevanja še vedno terensko delo in zato so študenti ter učitelji geografije osnovnih in srednjih šol pogosto izražali željo po pripravi podobnega priročnika, ki bi olajšal delo pri proučevanju prsti v naravi. Napotki za delo na terenu so sicer dostopni v nezadostni in raztreseni obliki po različni literaturi, ki je pogosto v tujem jeziku. Izjemno obsežen, še bolj raztresen, a hkrati kritično povsem neovrednoten vir so tudi spletne strani. Zato povsem razumemo uporabnike že obstoječega laboratorijskega priročnika, da so si zaželeli relevantnega izbora preizkušenih metod v slovenskem jeziku, ki bi jih bilo mogoče uporabiti pri terenskem proučevanju. Avtorja laboratorijskega priročnika, dr. Ana Vovk Korže iz Maribora in dr. Franc Lovrenčak iz Ljubljane sta zato zavihala rokave in v izjemno kratkem času pripravila še en priročnik, namenjen terenskemu delu v pedogeografiji.

Priročnik sta avtorja tokrat zasnovala še bolj široko in nima strogo določenega ciljnega uporabnika, glede na njegovo predznanje o prsteh. Vsakdo bo v priročniku našel sebi najprimernejšo metodo, s katero bi želel spoznavati prsti v njihovem naravnem okolju. Večina metod je namreč zasnovanih na dveh nivojih - osnovnem in zahtevnejšem. Za osnovni nivo ni potrebno nikakršno predznanje. Namenjen je osnovnošolcem in naključnim ljubiteljem narave, torej tistim, ki jih prsti zanimajo na spoznavnem in poljudnem nivoju. Za takšno poljudno spoznavanje prsti skorajda ne potrebujemo nikakršnih pripomočkov, le prosti čas, lepo vreme in željo po odkrivanju novega.

Zahtevnejša stopnja pa dejansko vključuje vse tiste metode in postopke, s katerimi praktično do obisti spoznamo prsti v naravi. Še več, obenem se naučimo tudi kako na terenu pravilno vzamemo vzorce, ki jih bomo kasneje analizirali v laboratoriju. Uporaba metod zahtevnejšega nivoje pričakuje vsaj osnovno zanje o prsteh, poznavanje geografske in pedogeografske terminologije, čeprav so v uvodih poglavij in podpoglavij temeljito razloženi predmet proučevanega parametra in uporabljena metoda. Narava nekaterih metod narekuje, da jih je mogoče izvajati le na osnovnem oziroma zahtevnejšem nivoju. Če je le mogoče, so postopki zasnovani tako, da so pripomočki dostopni vsem, si jih je mogoče lastnoročno izdelati ali pa so po nizkih cenah dostopni tudi v nespecializiranih trgovinah.

$\mathrm{Na}$ začetku nas priročnik najprej pripravi za delo na terenu (seznanitev z literaturo, kartografskim gradivom in pripomočki). V nadaljevanju sta se avtorja držala preverjenega načina predstavitve postopkov, ki se je izkazal kot izjemno dobrodošel že v laboratorijskem priročniku. Vsako podpoglavje, ki opisuje izbrano metodo, predstavi najprej pripomočke, ki jih potrebujemo za izvedbo in potek samega dela. Posebej nas opozarja, na kaj moramo biti pozorni, da bodo meritve pravilno izvedene, na koncu pa izvemo, kaj dobljeni rezultati 
pomenijo, kako izmerjeni parametri vplivajo na ostale lastnosti prsti in kako si z njihovo pomočjo razložimo nekatere pojave in procese v pokrajini.

Tudi v terenskemu priročniku je nekaj metod, ki niso nove in so poznane vsakemu geografu: kopanje pedološke jame, določevanje horizontov, vlažnosti, teksturnih razredov, deleža kalcijevega karbonata, reakcije, če naštejemo samo nekatere. Vendar so za lažje izvajanje in boljše razumevanje vsi postopki grafično in slikovno obogateni ter izpopolnjeni z najnovejšimi spoznanji o prsteh. Mnogo postopkov je na geografskem področju povsem novih in jih tudi na visokošolski stopnji do sedaj nismo uporabljali. Mednje prištevamo določanje vonja prsti, izdelave pomanjšanega profila prsti, sposobnost zadrževanja vode in ugotavljanje prisotnosti ter količine dušikovih, fosforjevih in organskih spojin v prsteh.

Samostojno pedogeografsko raziskovanje nam še dodatno olajšata pregled slovenske klasifikacije tipov prsti in razprostranjenost in opredelitev svetovnih tipov prsti po FAO UNESCO klasifikaciji.

V zadnjem delu so v prilogah zbrani terenski obrazci za popis prsti in tipi nalog, ki jih lahko uporabimo pri preučevanju prsti.

Priročnik za spoznavanje prsti na terenu skupaj s priročnikom za laboratorijske analize prsti v geografiji celovito zaokroži metodološko predstavitev geografskega proučevanja prsti in jo osvetli z vseh aspektov. Oba skupaj sta se že izkazala kot nepogrešljiva pripomočka pri terenskemu, kabinetnemu in laboratorijskemu proučevanju pedosfere, zato ob tem upravičeno upamo, da se bo pričujoča praksa uveljavila tudi na nekaterih drugih področjih geografije.

Blaž Repe 